JIEBAR : Journal of Islamic Education: Basic and Applied Research

Vol. 01, Nomor 01, April 2020

P-ISSN: $x x x x-x x x x$

DOI:

E-ISSN: xxxx-xxxx

http://e-journal.stit-islamic-village.ac.id/index.php/JIEBAR

\title{
PENGARUH PENDIDIKAN AGAMA ISLAM TERHADAP PEMBELAJARAN ANTIKORUPSI DI SMAN 6 KABUPATEN TANGERANG
}

\author{
Ahmad Aziz Faozi \\ Sekolah Tinggi Ilmu Tarbiyah Islamic Village Tangerang \\ Email: azizfaozi46@gmail.com
}

Received: 27 Februari 2020.

Accepted: 22 Maret 2020.

Published: 7 April 2020.

\begin{abstract}
This study aims to obtain empirical data on the Effects of Islamic Religious Education on Anti-Corruption Learning in SMA Negeri 6 Tangerang. The method used in this research is a quantitative descriptive method with the method of calculating the correlation study approach and is supported by the calculation of Statistical Product and Service Solutions (SPSS) version 21.0, in order to produce accurate data. In this study, the population was 116 students of SMA Negeri 6 Tangerang. Samples were taken as many as 30 students. By using random sampling techniques, the instrument used as a tool in data collection in the form of a behavior scale (Likert) to determine and measure Islamic Religious Education in a school scope. Data analysis uses the Product Moment and Statistical Product and Service Solutions (SPSS) formulas, which produce Rcounts greater than Rtable $(0.564>0.374)$, in this case Ho is rejected and $\mathrm{Ha}$ is accepted. And the coefficient of determination shows $31.36 \%$. This means that the level of influence is sufficient or moderate. This study concludes that between variables $\mathrm{X}$ and $\mathrm{Y}$ there is a positive and significant effect between Islamic Religious Education in anti-corruption learning in SMA Negeri 6 Tangerang. So that it can be interpreted as the higher the score of Islamic Religious Education in schools, the score will be followed by anticorruption on students.
\end{abstract}

Keywords: Islamic Religious Education, Anti-Corruption Learning

\begin{abstract}
ABSTRAK
Penelitian ini bertujuan untuk mendapatkan data secara empiris mengenai Pengaruh Pendidikan Agama Islam Terbadap Pembelajaran Antikorupsi di SMA Negeri 6 Kabupaten Tangerang. Metode yang digunakan dalam penelitian ini adalah metode deskriptif kuantitatif dengan metode penghitungan pendekatan studi korelasi serta
\end{abstract}


didukung penghitungan Statistical Product and Service Solutions (SPSS) versi 21.0, guna menghasilkean data yang akurat. Pada penelitian ini yang menjadi populasi adalah siswa SMA Negeri 6 Kabupaten Tangerang yang berjumlah 116 orang siswa. Sampel diambil sebanyak 30 orang siswa. Dengan menggunakan teknik pengambilan sampel secara random, Instrumen yang digunakan sebagai alat dalam pengambilan data berupa skala perilaku (likert) untuk mengetahui dan mengukur Pendidikan Agama Islam dalam sebuah ruang lingkup sekolah. Analisis data menggunakan rumus Product Moment dan Statistical Product and Service Solutions (SPSS), yang mengahsilkean rhitung lebih besar dari rtabel $(0,564>0,374)$, dalam hal ini maka Ho ditolak dan Ha diterima. Dan angka koefisien determinasi menunjukan 31,36\%. Artinya tingkat pengarubnya cukup atau sedang. Penelitian ini menyimpulkan bahwa antara variabel $X$ dan variabel $Y$ terdapat pengaruh yang positif dan signifikan antara Pendidikan Agama Islam dalam pembelajaran antikorupsi di SMA Negeri 6 Kabupaten Tangerang. Sebingga dapat diinterprestasikan ketika semakin tinggi sebuah skor Pendidikan Agama Islam dalam sekolah maka akan diikuti skor antikorupsi pada siswa.

Kata Kunci: Pendidikan Agama Islam, Pembelajaran Antikorupsi

\section{PENDAHULUAN}

Korupsi menurut istilah berasal dari bahasa latin Corruption atau Corruptus yang berarti kerusakan atau kebobrokan (Prodjohamidjojo, 2011: 7). Korupsi dalam Kamus Besar Bahasa Indonesia diartikan buruk, rusak, busuk, suka memakai barang atau uang yang dipercayakan kepadanya (memakai kekuasaannya untuk kepentingan pribadi) (Departemen Pendidikan Nasional, 2002: 55). Korupsi merupakan tindakan yang dapat menyebabkan sebuah negara menjadi bangkrut dengan efek yang luar biasa seperti hancurnya perekonomian, rusaknya sistem pendidikan dan pelayanan kesehatan yang tidak memadai. Dilingkungan sekolah sangat banyak ditemui praktek-praktek korupsi, mulai dari yang paling sederhana seperti mencontek, berbohong, melanggar aturan sekolah, terlambat datang sampai pada menggelapkan uang pembangunan sekolah.

Perebutan manusia atas sumber daya alam dan politik inilah awal mula terjadinya ketidakadilan. Padahal kebutuhan untuk bertanggung jawab hidup kian menanjak, tapi kesempatan untuk memenuhinya semakin terbatas. Sejak saat itu, moralitas dikesampingkan. Orientasi hidup yang mengarah pada keadilan berubah menjadi kehidupan saling menguasai dan mengekploitasi. Dalam sejarah dapat menemukan banyak catatan yang terkait dengan kondisi tersebut (Jusuf Kalla, 2009: 3-4).

JIEBAR : Journal of Islamic Education: Basic and Applied Research Vol. 01, Nomor 01, April 2020 
Korupsi pada dasarnya seperti penyakit yang berbahaya yang sulit disembuhkan. Jika sudah melakukannya sekali, sudah dipastikan penyakit ini akan menjadi komplikasi bagi seseorang yang melakukannya. Dalam sudut pandang Islam korupsi ini dapat dianalogikan sebagai kegiatan mencuri, ataupun merampok. Dalam Islam seseorang yang melakukan hal seperti itu sudah termasuk dosa besar. Orang yang mencuri dan merampok wajib dihukum, dalam al-Qur'an dijelaskan : (Departemen Agama RI, 2005: 115)

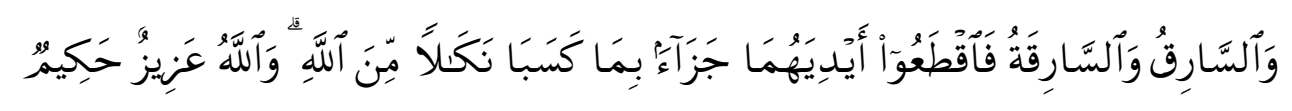

Artinya: "Adapun laki-laki yang mencuri dan perempuan yang mencuri, potonglah tangan keduanya (sebagai) pembalasan bagi apa yang mereka kerjakan dan sebagai siksaan dari Allah. dan Allah Maha Perkasa lagi Maha Bijaksana." (Q.S Al-Maidah : 38)

Mencuri sama halnya dengan korupsi mengambil harta orang lain dengan jalan diam-diam, diambil dari tempat penyimpananya. Mencuri adalah sebagian dari dosa besar. Orang yang mencuri wajib dihukum, yaitu dipotong tangannya. Apabila ia mencuri untuk pertama kalinya, maka dipotong yang kanan (dari pergelangan telapak tangan), bila mencuri kedua kali, dipotong kaki kirinya (dari ruas tumit), mencuri yang ketiga tanganya yang kiri, dan yang keempat dipotong kakinya yang kanan. Kalau dia masih juga mencuri dipenjarakan sampai tobat (Sulaiman, 2012: 440-441).

Tidak menutup kemungkinan bahwa terpuruknya bangsa ini bukan karena sumber daya manusianya yang tidak cerdas dan tidak pintar, tetapi karena telah terjadinya degradasi moral dan akhlak. Karena jika berkaca pada kaum-kaum terdahulu, Allah menghancurkan mereka bukan karena mereka tidak pintar tetapi karena akhlak yang sudah bobrok. Karena para pemimpin yang tidak memiliki keimanan yang kuat, akhlak yang baik maka dengan ilmunya mereka akan melakukan korupsi, penyalahgunaan jabatan, dan dengan kekayaan mereka akan meghalalkan berbagai cara demi mendapatkan kekuasaan dan jabatan.

Dalam dunia pendidikan ternyata kegiatan korupsi sudah menjadi culture yang diimplementasikan dalam aktivitas siswa/i. Korupsi jika dianalogikan dalam pendidikan dapat dikatakan sebuah kegiatan tidak jujur ataupun berbohong, misalnya seseorang siwa/i mencontek ketika ulangan atau ujian, membeli makanan di warung maupun kantin kejujuran namun tidak 
sesuai dengan harga yang telah ditentukan, membolos diwaktu jam pelajaran, memakai uang SPP bayaran untuk kebutuhan pribadinya. Jika hal ini sudah menjadi culture maka dapat dipastikan generasi penerus bangsa dalam mencetak manusia yang pintar dan bermoral akan terpuruk.

Beberapa tahun terakhir mulai menguat perhatian banyak pihak terhadap perlunya upaya preventif yang lebih menyentuh masyarakat akar rumput sekaligus melahirkan generasi bersih korupsi, salah satunya melalui jalur pendidikan. Pendidikan, dalam arti luas, pada hakikatnya akan selalu eksis sepanjang kehidupan manusia dan secara silmultan memperbaiki kualitas kemanusiaan manusia, melalui perbaikan akal dan budi.

Untuk meningkatkan kualitas sumber daya manusia. Pendidikan memegang peran yang sangat penting. Sumber daya manusia yang sesuai kebutuhan pembangunan bangsa hanya akan lahir dari sistem pendidikan yang berdasarkan filosofis bangsa itu sendiri. Oleh karena itu, upaya untuk melahirkan suatu sistem pendidikan nasional yang berwajah Indonesia dan berdasarkan pancasila harus terus dilaksanakan dan semangat untuk itu harus dilaksanakan dan semangat untuk itu harus terus menerus diperbaharui.

Tantangan utama bangsa ini dan di masa depan adalah kemampuan untuk meningkatkan kualitas sumber daya manusia. Dalam kaitan ini menarik untuk dikaji bagaimana kualitas pendidikan kita dan upaya apa yang dapat dilakukan untuk meningkatkan kualitas pendidikan sehingga menghasilkan sumber daya manusia yang lebih berkualitas sebagaimana yang diharapkan, agar bangsa Indonesia menjadi bangsa yang produktif, efesien, dan memiliki kepercayaan diri yang kuat sehingga mampu bersaing dengan bangsa-bangsa lain dalam kehidupan global (Zamroni, 2000: 33).

Di Indonesia yang memiliki masyarakat mayoritas memeluk Agama Islam, seharusnya Pendidikan Agama Islam (PAI) mendasari pendidikan lain. serta menjadi primadona bagi masyarakat, orang tua, dan peserta didik. PAI juga seharusnya mendapatkan waktu yang proporsional, tidak saja di madrasah atau sekolah-sekolah bernuansa Islam, tetapi sekolah-sekolah umum. Demikian halnya dalam upaya peningkatkan mutu pendidikan, PAI harus dijadikan tolak ukur dalam membentuk watak dan pribadi peserta didik, serta membangun moral bangsa (nation character building). 


\section{METODE PENELITIAN}

Pendekatan yang digunakan dalam penelitian ini yaitu metode penelitian kuantitatif dengan jenis penelitian korelasional, yaitu penelitian yang dimaksudkan untuk mengetahui ada atau tidaknya hubungan antara dua variabel atau lebih. Penelitian kuantitatif adalah penelitian yang berlandaskan pada filsafat positivisme, realitas dipandang sebagai sesuatu yang kongkrit, obyektif, terukur, rasional, dan sistematis (Sugiyono, 2017: 7).

\section{Definisi Konseptual}

Konsep yang akan di observsasi dalam penelitian ini merupakan mengenai pendidikan Agama Islam terhadap pembelajaran antikorupsi di SMA Negeri 6 Kabupaten Tangerang. Adapun pengertian dari dua konsep tersebut adalah:

a. Pendidikan Agama Islam dalam sebuah ruang lingkup sekolah atau lembaga pendidikan adalah suatu proses aktivitas yang meliputi kegiatan spiritual, akhlak, iman, maupun sosial yang terjadi dalam sekolah itu sendiri yang dilakukan secara sadar oleh siswaataui.

b. Pembelajaran antikorupsi yaitu dimana sebuah aktivitas siswaataui yang melakukan sesuatu yang berhubungan langsung dengan sikap tanggung jawab, kejujuran maupun kedisiplinan yang dilakukan di sekolah.

\section{Definisi Operasional}

Yang dimaksud dengan variabel bebas dalam peneltian adalah variabel $\mathrm{X}$ yaitu "Pendidikan Agama Islam di SMA Negeri 6 Kabupaten Tangerang", dan indikatornya adalah sebagai berikut :

a. Pendidikan Akhlak

b. Pendidikan Iman

c. Pendidikan Ibadah

Sedangkan yang menjadi yang menjadi variabel terikat dalam penelitian adalah variabel Y yaitu "Pembelajaran Antikorupsi di SMA Negeri 6 Kabupaten Tangerang", dan yang menjadi indikatornya adalah sebagai berikut:
a. Kedisiplin Waktu
b. Sikap Jujur 


\section{c. Sikap Tanggung Jawab}

\section{Populasi dan Sampel}

Pengertian populasi merupakan keseluruhan obyek penelitian. Populasi adalah kelompok subyek baik yang berbentuk manusia, gejala-gejala, nilai tes, benda-benda atau sesuatu peristiwa (Sugiyono, 2017). Jadi populasi bersifat umum dan meliputi berbagai keadaan. Dalam penelitian kali ini populasinya adalah adalah siwaataui khususnya kelas XI IIS 2 (IPS 2), XI IIS 3 (IPS 3), dan XI IIS 4 (IPS 4) di SMA Negeri 6 Kabupaten Tangerang sebanyak 116 orang.

Sedangkan yang dimaksud dengan sampel adalah bagian dari keseluruhan obyek penelitian (populasi) yang dipandang sebagai wakil dari populasi. Hal ini dimaksudkan untuk memperkecil obyek yang diteliti sehingga peneliti dapat dengan mudah mengorganisasikan agar dapat diperoleh hasil yang obyektif. Penulis memilih sampel sebanyak 30 0rang yang dianggap bisa mewakili dari keseluruhan populasi.

\section{Perumusan Hipotesis}

Oleh karena hipotesis ini merupakan suatu anggapan sementara yang masih harus dibuktikan sebuah kebenarannya. Maka dalam merumuskan sebuah hipotesa terdapat dua bentuk hipotesis, yaitu hipotesis alternatif $\left(\mathrm{H}_{\mathrm{a}}\right)$ dan hipotesis nihil $\left(\mathrm{H}_{\mathrm{o}}\right)$. Hipotesis alternatif $\left(\mathrm{H}_{\mathrm{a}}\right)$ yaitu apabila terdapat korelasi positif yang signifikan, antara variabel $\mathrm{X}$ (Pendidikan Agama Islam) dan variabel Y (Pembelajaran Antikorupsi), sedangkan hipotesis nihil $\left(\mathrm{H}_{\mathrm{o}}\right)$ yaitu apabila tidak ada korelasi positif yang signifikan antara variabel $\mathrm{X}$ dan $\mathrm{Y}$.

\section{Teknik Analisis Data}

Pendekatan yang digunakan dalam penelitian ini mengumpulkan data berupa analisis korelasi digunakan untuk mengetahui hubungan antara satu variabel dengan variabel lainnya. Antara variabel bebas (Pendidikan Agama Islam di SMA Negeri 6 Kabupaten Tangerang) Dengan variabel terikat (Pembelajaran Antikorupsi di SMA Negeri 6 Kabupaten Tangerang) dengan menggunkan rumus dibawah ini:

\section{Rumus korelasi product moment $\left(\mathrm{r}_{\mathrm{xy}}\right)$}

$$
\mathrm{r}_{\mathrm{xy}}=\frac{N \sum X Y-\left(\sum X\right)\left(\sum Y\right)}{\sqrt{\left[N \sum X^{2}-\left(\sum X\right)^{2}\right]\left[\sum Y^{2}-\left(\sum Y^{2}\right)\right]}}
$$


Dimana :

$$
\begin{array}{ll}
\mathrm{r}_{\mathrm{xy}} & =\text { Koefisien korelasi } \\
\mathrm{n} & =\text { Jumlah sampel } \\
\sum \mathrm{x} & =\text { Jumlah skor variabel } \mathrm{x} \\
\sum \mathrm{y} & =\text { Jumlah skor variabel } \mathrm{y} \\
\sum \mathrm{xy} & =\text { Jumlah skor antara } \mathrm{x} \text { dan } \mathrm{y} \\
\sum \mathrm{x}^{2} & =\text { Jumlah skor variabel } \mathrm{x} \text { yang dikuadratkan } \\
\sum \mathrm{y}^{2} & =\text { Jumlah skor varaibel y yang dikuadratkan }
\end{array}
$$

\section{Uji Regresi}

Dalam analisis regresi, akan dikembangkan sebuah estimiating equation (persamaan regresi), yaitu formula yang mencari nilai variabel dependen dari nilai independen yang diketahui. Analisis regresi digunakan terutama untuk tujuan peramalan, dimana dalam model tersebut ada sebuah variabel dependen (tergantung) dan variabel independen (bebas)(Singgih, 2000, 330). Dengan kata lain sebuah metode yang digunakan untuk menguji pengaruh antar variabel satu sama lain dan bisa menjadi faktor pendukung atau penguat penghitungan uji korelasi product moment.

\section{Uji Koefesiensi Determinasi $\left(\mathbf{r}^{2}\right)$}

Untuk menentukan besarnya koefesien determinasi menggunakan rumus dibawah ini:

$$
\mathrm{KD}=r^{2} \times 100 \%
$$

Keterangan:

$$
\begin{aligned}
& \mathrm{KD}=\text { Koefisien Determinasi } \\
& \mathrm{R}=\text { Korelasi koerlasi variabel terikat bebas dengan variabel terikat. }
\end{aligned}
$$

\section{Uji Normalitas}

Uji normalitas yaitu untuk melihat apakah nilai residual terdistribusi normal atau tidak. Model regresi yang baik adalah memiliki nilai residual yang terdistribusi normal. Jadi uji normalitas bukan dilakukan pada masing-masing variabel tetapi pada nilai residualnya. Sering terjadi kesalahan yang jamak yaitu bahwa uji normalitas dilakukan pada masing-masing variabel. Hal ini tidak 
dilarang tetapi model regresi memerlukan normalitas pada nilai residualnya bukan pada masing-masing variabel penelitian.

\section{Uji Heteroskedastisitas}

Uji heteroskedastisitas yaitu untuk melihat apakah terdapat ketidaksamaan varians dari residual satu ke pengamatan ke pengamatan yang lain. Model regresi yang memenuhi persyaratan adalah dimana terdapat kesamaan varians dari residual satu pengamatan kepengamatan yang lain tetap atau disebut homoskedastisitas.

Deteksi heteroskedastisitas dapat dilakukan dengan metode scatter plot dengan memplotkan nilai ZPRED (nilai prediksi) dengan SRESID (nilai residualnya). Model yang baik didapatkan jika tidak terdapat pola tertentu pada grafik, seperti mengumpul ditengah, menyempit kemudian melebar atau sebaliknya melebar kemudian menyempit.

\section{HASIL DAN PEMBAHASAN}

\section{KAJIAN TEORITIS}

Tujuan pendidikan nasional untuk berkembangnya potensi peserta didik agar menjadi manusia yang beriman dan bertakwa kepada Tuhan Yang Maha Esa, berakhlak mulia, sehat, berilmu, cakap, kreatif, mandiri, dan menjadi warga negara yang demokratis serta tanggung jawab (Republika, 2003: 7). Dalam mencapai tujuan pendidikan nasional tidak semudah membalikan telapak tangan karena peran dan fungsi Pendidikan Agama Islam sedemikan besar dalam penentuan tercapainya tujuan pendidikan termasuk dalam menciptakan kondisi masyarakat yang adil, sejahtera dan makmur. Namun, tujuan pendidikan belum bisa dikatakan berhasil. Menurut salahudin, bangsa ini sedang mengalami bencana sosiologis dan psikologis maraknya penyakit alenasi atau kegamangan jiwa. Salah satunya adalah terkontaminasi budaya koruptif (Anas, 2013: 15-16).

Dalam hal ini ada beberapa pandangan yang berbeda dalam mendefinisikan apa itu Pendidikan Agama Islam, yaitu pendidikan yang melatih perasaan peserta didik dengan cara tertentu sehingga dalam sikap hidup, tindakan, keputusan, dan pendekatan terhadap segala jenis pengetahuan sangat dipengaruhi oleh nilai-nilai spritual dan sadar akan nilai etis Islam, ada dua hal yang harus ditekankan. Pertama, pendidikan Islam adalah aktivitas 
pendidikan yang diselenggarakan atau didirikan dengan hasrat dan niat untuk mengejawantahkan ajaran dan nilai-nilai Islam. Kedua, pendidikan Islam adalah sistem pendidikan yang diekmbangkan dan disemangati niai-nilai Islam (Sri Minarti, 2013: 25-26).

Pandangan berbeda tentang pendidikan yang mengatakan suatu usaha untuk membina dan mengasuh peserta didik agar senantiasa dapat memahami ajaran Islam secara menyeluruh. Lalu mengahayati tujuan, yang pada akhirnya dapat mengamalkan serta menjadikan Islam sebagai pandangan hidup. Pandangan lain mengatakan Pendidikan Agama Islam merupakan sebagai usaha sadar generasi tua untuk mengalihkan pengalaman, pengetahuan, kecakapan, dan keterampilan kepada generasi-generasi muda agar kelak menjadi manusia bertakwa kepada Allah.

Berapa banyak orang yang berubah jalan hidup dan keyakinannya dalam waktu yang sangat pendek, dari seseorang penjahat tiba-tiba menjadi seorang yang baik, rajin, dan tekun beribadah. Seolah-olah ia dalam waktu singkat dapat berubah menjadi orang lain sama sekali. Sebaliknya juga terjadi, orang yang berubah dari patuh dan tunduk kepada agama, menjadi orang yang lalai atau suka menentang agama.

Untuk menciptakan kesejahteraan dan ketenangan dalam berkarya perlu selalu dilandasi dengan norma/etika dan Agama, tanpa keduanya ini akan dapat menimbulkan bahaya. Dalam Agama Islam, khususnya pendidikan Islam, dipandang sebagai pengikat dan penuntun kejalan yang lurus, sehingga budaya yang akan timbul akan dapat memberi manfaat, bukan saja kepada dirinya sendiri, tetapi juga orang lain.

Pola pendidikan Islam akan dapat membimbing manusia untuk memperoleh akal pikiran yang sehat dan rasional dalam rangka menunjang terciptanya insan kamil. Dengan demikianlah dapat mewariskan norma dan etika yang religius kepada generasi selanjutnya. Firman Allah SWT dalam surat Ad-Dukhaan ayat 28 yang berbunyi: (Departemen Agama, 2005: 498)

"Demikinalah. dan Kami wariskan semua itu kepada kaum yang lain" (Q.S Ad-Dukhaan : 28)

Dengan sistem pewarisan pendidikan kepada generasi muda atau pelanjut, berarti mengandung pelestarian budaya kepada kelompok penerus. 
Tugas dan tanggung jawabnya adalah melestarikan kewajiban pendidikan secara estafet. Bukan saja bimbingan dan nilai-nilai moral, tetapi juga akhlak dan tingkah laku sehari-hari di masyarakat. Tanggung jawab itu perlu memeilihara dan mengembangkan ketentraman dan kelestarian manusia dan alam lingkungan (Endin Nasrudin, 2009: 29-30).

Sesungguhnya pertumbuhan kesadaran moral pada anak menyebabkan anak mendapat pencerahan baru sehingga menambah perhatiannya terhadap nasihat-nasihat agama, dan kitab suci baginya tidak lagi merupakan kumpulan undang-undang, yang dengan itu Allah menghukum dan mengatur dunia guna menunjukan kepada kita kepada kebaikan

Islam merupakan syariat Allah yang diturunkan kepada umat manusia dimuka bumi agar mereka beribadah kepadanya. Penanaman keyakinan terhadap Tuhan hanya bisa dilakukan melalui proses pendidikan baik di rumah, sekolah, maupun lingkungan. Pendidikan Islam merupakan kebutuhan manusia sebagai mahluk pedagogis manusia dilahirkan dengan membawa potensi dapat dididik dan mendidik sehingga mampu menjadi khalifah di bumi, serta pendukung dan pemegang kebudayaan.

Pendidikan Agama Islam (PAI) di sekolah bertujuan untuk menumbuhkan dan meningkatkan keimanan melalui pemberian dan pemupukan pengetahuan penghayatan, pengamalan serta pengalaman peserta didik tentang Agama Islam sehingga menjadi manusia muslim yang terus berkembang dalam hal keimanan, ketakwaanya, berbangsa dan bernegara, serta untuk dapat melanjutkan pada jenjang pendidikan yang lebih tinggi.

Oleh karena itu berbicara Pendidikan Agama Islam (PAI), baik makna maupun tujuannya haruslah mengacu pada penanaman nilai-nilai Islam dan tidak dibenarkan melupakan etika dalam rangka menunaikan keberhasilan hidup di dunia bagi anak didik yang kemudian akan mampu membuahkan kebaikan di akhirat. Manusia lahir tidak mengetahui sesuatu apapun, tetapi ia dianugrahkan oleh Allah pancaindra, pikiran, dan rasa sebagai modal untuk menerima ilmu pengetahuan, memiliki keterampilan dan mendapatkan sikap tertentu melalui proses kematangan belajar terlebih dahulu. Untuk mencapai hal yang diinginkan itu dapat diusahakan melalui pendidikan, baik pendidikan dalam keluarga, pendidikan di sekolah, maupun pendidikan di masyarakat. 
Jadi, pendidikan Agama Islam merupakan Ikhtiar manusia dengan jalan bimbingan dan pimpinan untuk membantu dan mengarahkan fitrah Agama si anak didik menuju terbentuknya kepribadian utama sesuai dengan ajaran Agama. Dengan demikian akhlak merupakan barometer yang dapat dijadikan ukuran untuk menilai kadar iman seseorang. Seseorang baru bisa dikatakan memiliki kesempurnaan iman apabila dia memiliki budi pekerti ataupun akhlak yang mulia.

Korupsi secara harfiyah merupakan Kejahatan, kebusukan, dapat disuap, tidak bermoral, kebejatan dan ketidakjujuran. Perbuatan yang buruk seperti menggelapan uang, penerimaan uang sogok, dan sebagainya. (Evi, 2008: 8) Istilah korupsi sesungguhnya sangat luas, mengikuti perkembangan kehidupan masyarakat yang semakin kompleks serta semakin canggih teknologi, sehingga mempengaruhi pola pikir, tata nilai, aspirasi, dan strukutur masyarakat dimana bentuk-bentuk kejahatan yang semula terjadi secara tradisional berkembang kepada kejahatan inkovensional yang semakin sulit untuk diikuti oleh norma hukum yang telah ada.

Kejahatan inkovensional menyentuh segala aspek kehidupan bangsa, mulai dari kepentingan hak asasi, ideologi, hingga lainnya yang menyangkut aspek perekonomian keuangan negara. Korupsi salah satu jenis kejahatan yang semakin sulit dijangkau oleh aturan hukum pidana, karena perbuatan korupsi bermuka majemuk yang memerlukan kemampuan berpikir aparat pemeriksa dan penegak hukum disertai pola perbuatan yang sedemikian rapih. Oleh karena itu, perubahan dan perkembangan hukum merupakan salah satu untuk mengantisipasi korupsi tersebut (Surachmin, 2011: 10-11).

Dewasa ini korupsi memang sudah seperti polusi yang menyebar luas sehingga sulit untuk menghindarinya yang dapat merusak gangguan kesehatan. Hal ini bisa dilihat dari kejadian-kejadian yang berada disekitar kita tanpa mengenal usia, ras, suku, jabatan, ataupun hal lainnya. Mungkin untuk menghindari polusi yang seperti ini kita harus memakai pakaian yang lebih tertutup agar polusi tidak bisa merusak kesehatan kita.

Indonesia merupakan negara yang secara resmi menyatakan, ketuhanan Yang Maha Esa sebagai salah satu dasar bernegara dalam konstitusinya. Artinya, Indonesia memproklamasikan bahwa nilai keutuhan 
merupakan pijakan dan rujukan nilai, menjadi pilar pertimbangan dalam berpikir serta bertindak dalam hidup berbangsa dan bernegara. Dengan demikian, kegiatan kenegaraan pun memiliki dasar metafisis dan spritual sehingga diharapkan komitmen moral tumbuh kuat dalam diri anak bangsa yang lahir dari kesadaran bahwa semua perbuatan dan tingkah laku manusia adalah bermakna, bernilai, dan akan dipertanggung jawabkan dihadapan Tuhan.

Sesungguhnya nilai ketuhanan tersebut telah berakar kuat dalam pola hidup masyarakat di Nusantara. Nilai ketuhanan itu merupakan khazanah kearifan yang terajut dan tersimpan rapih, baik dalam format Agama maupun sebuah sistem kepercayaan yang berumur ratusan atau bahkan ribuan tahun. Karena itu, kita bisa temukan aneka bentuk kepercayaan dan agama dari Sabang sampai Merauke. Artinya, walaupun Indonesia tidak mendefinisikan diri sebagai negara beragama, agama diakui eksistensinya sebagai sumber nilai, menjadi rujukan dalam perilaku publik. Maka tidak salah jika Indonesia adalah bangsa religius.

Klaim bahwa bangsa Indonesia merupakan bangsa religius memiliki konsekuensi logis, yaitu dalam kehidupan keseharian di ruang privat dan publik. Jadi, seharusnya kehidupan sosial, ekonomi, politik, budaya bangsa Indonesia diwarnai oleh nilai dan norma luhur Agama. Namun pada hakikatnya negara yang berketuhanan tersebut tercabik dan luluh lantah oleh fakta merajalelanya praktik korupsi pada hampir semua lini birokrasi mulai dari tingkat lokal sampai tingkat pusat, serta pada semua sendi kehidupan masyarakat (Jusuf Kalla, 2009: 809-810). Di dalam Islam, konsep atau istilah yang sering dikaitkan dengan korupsi karena ditinjau dari perspketif sebagai penghianatan atas amanah yang semestinya dipelihara ialah Gbulul. Ghulul secara leksikal dimaknai "akbdzu al-syai wa dassabu fi mata'bi” yang artinya "mengambil sesuatu dan menyembunyikannya dalam hartanya." Dalam sejarah Islam, konsep ghulul muncul karena adanya penggelapan harta rampasan perang sebelum dibagikan. Di dalam al-Qur'an dijelaskan sebagaimana firman Allah yang berbunyi: (Departemen Agama RI, 2005: 72) 


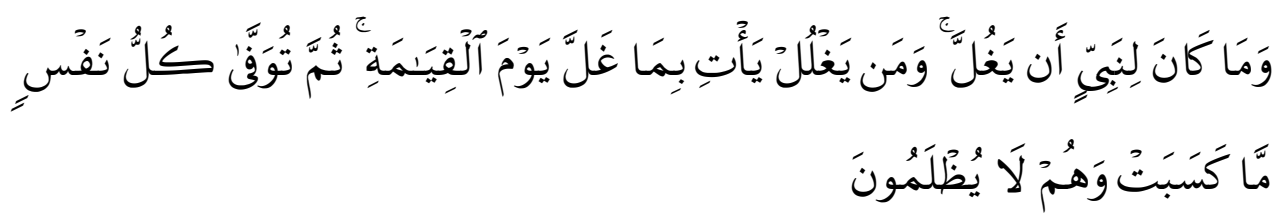

Artinya: "Dan tidak mungkin seorang Nabi berkbianat dalam urusan harta rampasan perang. Barangsiapa yang berkbianat dalam urusan rampasan perang itu, Maka pada hari kiamat ia akan datang membawa apa yang dikhianatkannya itu, kemudian tiap-tiap diri akan diberi pembalasan tentang apa yang ia kerjakan dengan (pembalasan) setimpal, sedang mereka tidak dianiaya”.(Q.S AliImran :161)

Rasulullah memperinci makna ghululini meliputi tindakan seorang yang mengambil suatu penghasilan diluar gajinya yang sudah ditetapkan dan orang yang mendapatkan hadiah yang melekat pada dirinya. Perbuatan korupsi menjadi penyebab kehinaan dan siksa api neraka pada hari Kiamat. Dalam hadits Ubadah bin ash Shamit r.a, bahwa Nabi Muhammad Saw bersabda: (HR. Ibnu Majah)

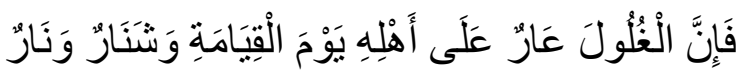

Artinya: "......Karena sesunggubnya ghulul (korupsi) itu adalab kebinaan, aib dan api neraka bagi pelakunya"

Orang yang mati dalam keadaan membawa harta ghulul (korupsi), ia tidak mendapat jaminan atau terhalang masuk surga. Selain konsep ghulul, didalam Islam dikenal juga Istilah risywah, dalam terminologis adalah tindakan memberikan harta dan yang sejenis untuk membatalkan hak milik pihak lain atau mendapatkan atas milik pihak lain. Dalam bahasa dapat diartikan sebagai sogok. Sebagaimana firman Allah yang berbunyi: (Departemen Agama RI, 2005: 181).

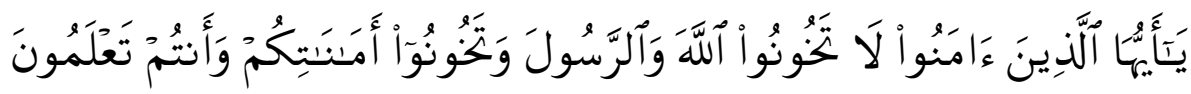

Artinya: "Wabai orang-orang yang beriman, janganlah kamu mengkbianati Allab dan Rasul (Mubammad) dan (juga) janganlah kamu mengkbianati amanat-amanat yang dipercayakan kepadamu, sedang kamu mengetahui”.(Q.S Al-Anfal : 27)

Dalam ayat di atas dijelaskan bahwa jenis korupsi termasuk dalam arti khianat. Di dalamnya dijelaskan tentang larangan mengkhianati amanat 
manusia beriringan dengan larangan mengkhianati Allah dan Rasul-Nya. Amanat manusia disini meliputi banyak hal dari amanat politik, ekonomi, bisnis, sosial, dan pergaulan.

Pendidikan antikorupsi merupakan usaha sadar dan terencana untuk mewujudkan proases belajar mengajar yang kritis terhadap nilai-nilai antikorupsi. Dalam proses tersebut, maka pendidikan antikorupsi bukan sekedar media bagi transfer pengetahuan (kognitif), namun juga menekankan pada upaya pembentukan karakter (afektif), dan kesadaran moral dalam melakukan perlawanan (psikomotorik), terhadap penyimpangan prilaku korupsi (Ari Wibowo, 2012: 38).

Untuk mewujudkan pendidikan antikorupsi, pendidikan di sekolah harus berorientasikan pada tataran moral action, agar peserta didik tidak hanya berhenti pada kompetensi saja, tetapi sampai memiliki kemauan, dan kebiasaan dalam mewujudkan nilai-nilai dalam kehidupan sehari-sehari.

Sebagaimana tujuan pendidikan antikorupsi dalam pemahaman perilaku antikorupsi yang merujuk pada UU No. 20 Tahun 2003 tentang Sistem Pendidikan Nasional Pasal 4 ayat 3 disebutkan bahwa pendidikan diselenggarakan sebagai suatu proses pembudayaan dan pemberdayaan peserta didik yang berlangsung sepanjang hayat. Atas dasar ini, signifikansi penyelenggaraan pendidikan antikorupsi lewat jalur pendidikan tidak dapat diabaikan potensinya sebagai salah satu cara untuk membudayakan antikorupsi di Indonesia. Pendidikan Islam sendiri mempunyai tujuan yang sangat mulia, yakni menciptakan peserta didik yang memiliki pengetahuan, sikap dan mental yang berakhlakul karimah menurut ajaran Islam (http://digilib.uinsby.ac.id80647BAB\%20V.pdf).

Secara etimologi, metode berasal dari bahasa Greek "meta" yang berarti melalui dan "hodos" yang berarti jalan. Sedangkan dalam pengertian yang umum "metode" diartikan cara mengerjakan sesuatu (Muzayin, 2000: 97). Dalam proses pendidikan, metode mempunyai peranan untuk mencapai suatu tujuan pendidikan yang telah ditentukan.

Metode juga diartikan sebagai cara yang paling baik, tepat (efektif), dan cepat (efisien). Efektif atau tidak dan efisien atau tidak suatu metode banyak bergantung kepada faktor-faktor yang meliputi situasi dan kondisi pemakai metode itu sendiri yang kurang memahami penggunaannya atau tidak sesuai dengan seleranya, atau secara obyektif metode ini kurang cocok dengan Dalam 
pandangan filosofis pendidikan, metode merupakan alat yang digunakan untuk mencapai tujuan pendidikan dan penggunaan metode dalam proses kependidikan pada hakikatnya merupakan pelaksanaan sikap hati-hati dalam pekerjaan mendidik atau mengajar. Ada dua metode yang dapat digunakan dalam pendekatan pendidikan antikorupsi (Soelaiman, 1992: 115-117), yaitu:

a. Metode Langsung

Mengadakan hubungan langsung secara pribadi dan kekeluargaan dengan individu-individu yang bersangkutan, yaitu dengan cara langsung mendatangi dan memberikan arahan serta bimbingan agar orang tersebut mempunyai keinginan untuk berbuat kebaikan atau jujur terhadap orang lain, juga diberikan contoh-contoh nyata dalam kehidupan sehari-hari.

b. Metode Tak Langsung

Mengadakan hubungan secara tidak langsung kepada individu/masyarakat yang menjadi sasaran, melainkan sasaran antara. Cara ini juga bisa dimanfaatkan walaupun tidak secara langsung menghadapi orang, karena dengan cara ini bisa memberikan nasehat pada orang lain setelah itu dia akan menyampaikannya pada orang tersebut.

Dengan menggunakan metode yang telah diuraikan di atas inilah, para pendidik diharapkan dapat menerapkannya pada pelaksanaan proses pendidikan antikorupsi dalam melaksanakan tugas kewajiban edukatifnya. Tujuan pendidikan antikorupsi akan tercapai apabila metode-metode tersebut dapat diamalkan dengan sungguh-sungguh dan disesuaikan dengan kebutuhan dalam pendidikan antikorupsi.

Di Indonesia metode yang paling menarik dari pendidikan antikorupsi dan telah banyak diadopsi diberbagai sekolah adalah laboratorium warung. kejujuran atau kantin kejujuran. Secara praktis, warung tersebut mengajarkan praktik kejujuran dengan aksentuasi transendental bahwa apapun yang kita lakukan pasti diketahui Allah. Warung tersebut dibuka tanpa penunggu (kasir), pembelinya membayar sesuai dengan harga, mencatat pembelian, dan mengambil uang kembalian dengan sendirinya.

Dalam Terapi Penyakit Korupsi, praktek korupsi terjadi karena individu tidak mempunyai nilai-nilai moral yang dapat mencegah korupsi yang dilakukannya. Hal situsional seperti adanya peluang korupsi tidak akan 
mendukung terjadinya korupsi apabila individu memiliki nilai moral yang terintegrasi menjadi kepribadian yang kokoh. Adapun metode yang dapat dilakukan untuk pendidikan antikorupsi dengan melalui tiga pendekatan (Abu Fida, 2006: xxii), yaitu:

a. Pendekatan Rasionalistik.

Yakni menanamkan moral dengan konsep-konsep yang bersifat rasional, misalnya dengan menanamkan pola fikir bahwa korupsi merupakan perbuatan yang merusak dan menghancurkan diri, lingkungan, dan negara. Dengan pendekatan ini akan tertanam pada individu (peserta didik) bahwa korupsi merupakan perbuatan yang merusak dan menghancurkan diri, lingkungan dan negara. Dengan pendekatan ini akan tertanam pada individu bahwa korupsi merupakan perbuatan yang harus dihindarkan dalam dirinya. Mereka tidak melakukan praktek korupsi bukan karena takut pada tuhan dan neraka, tetapi secara rasional mereka menyadari bahwa korupsi akan menghancurkan mereka dan negaranya.

b. Pendekatan Spiritualistik

Yaitu memanamkan moral dengan konsp-konsep yang bersifat spiritual, seperti dengan menanamkan rasa takut kepada tuhan dan azab-Nya. Dengan pendekatan ini akan diperoleh individu yang takut kepada azab tuhan-Nya, sehingga dirinya dapat menghindari untuk melakukan praktik korupsi.

c. Pendekatan kombinasi antara rasionalistik dan spiritualistik.

Yakni dengan mengabungkan pendekatan pertama dan kedua secara bersamaan, yakni disamping mengguanakan cara-cara yang rasionalistik, juga menggunakan metode-metode spiritualistik. Adapun cara-cara yang harus ditempuh dalam pendidikan antikorupsi agar hati untuk tidak melakukan praktek korupsi, antara lain:

1) Memulai kehidupan dengan niat yang ikhlas.

2) Menyikapi kehidupan dunia berdasarkan ajaran Agama.

3) Mengendalikan nafsu syahwat terhadap harta.

4) Menjaga pikiran yang terlintas dan langkah nyata untuk perbuatan.

5) Tawakal.

6) Mensyukuri nikmat harta yang ada padanya.

7) Sabar menghadapi kemiskinan dan fitnah (ujian) harta

8) Ridha terhadap qadha (ketentuan) Allah. 
9) Menumbuhkan rasa takut (khauf) kepada Allah.

10) Membentuk sifat jujur dalam diri.

11) Membangun sifat malu untuk berbuat maksiat.

12) Muhasabah (intropeksi diri).

13) Muraqabbatullah.

14) Menumbuhkan kecintaan (mahabbah) kepada Allah.

15) Bertaubat untuk tidak melakukan praktik korupsi.

Hal ini perlu ditanamkan pada individu (peserta didik) karena untuk menciptakan generasi baru yang antikorupsi merupakan sasaran dari langkah preventif untuk membantu mewujudkan negara yang bebas dari korupsi. Gerakan antikorupsi melalui jalur pendidikan merupakan langkah awal yang ditempuh untuk mulai melakukan penanaman nilai ke arah yang lebih baik. dari sejak usia muda dengan membangun karakter termasuk pembentukan sikap disiplin.

Jadi secara eksplisit tujuan pendidikan antikorupsi dalam Pendidikan Agama Islam (PAI) adalah:

a. Membentuk pengetahuan dan pemahaman mengenai bentuk korupsi dan aspek-aspeknya dalam dimensi Pendidikan Agama Islam (PAI).

b. Pendidikan Islam bisa memberikan sumbangsi tentang persepsi korupsi di Indonesia sehingga korupsi tidak lagi menjadi budaya.

c. Membentuk perilaku melawan korupsi yang didasari atas keyakinan bahwa ajaran Islam menentang keras perilaku ahumanis termasuk perbuatan korupsi.

Dalam penelitian ini nampak jelas bahwa para pendidik, maupun pakar serta penggiat beberapa lembaga pendidikan menyatakan bahwa pendidikan antikorupsi sangat diperlukan bagi segenap anak bangsa untuk memberikan pemahaman yang lebih luas tentang bahaya korupsi bagi kehidupan berbangsa dan bernegara.

\section{HASIL PENELITIAN}

Tabel 1. Penghitungan Korelasi Product Moment Untuk Pengujian Hipotesis

\begin{tabular}{cccccc}
\hline No & $\mathrm{X}$ & $\mathrm{Y}$ & $\mathrm{X} 2$ & $\mathrm{Y} 2$ & $\mathrm{XY}$ \\
\hline 1 & 66 & 52 & 4356 & 2704 & 3432 \\
\hline
\end{tabular}




\begin{tabular}{|c|c|c|c|c|c|}
\hline 2 & 55 & 56 & 3025 & 3136 & 3080 \\
\hline 3 & 76 & 67 & 5776 & 4489 & 5092 \\
\hline 4 & 53 & 53 & 2809 & 2809 & 2809 \\
\hline 5 & 55 & 50 & 3025 & 2500 & 2750 \\
\hline 6 & 65 & 62 & 4225 & 3844 & 4030 \\
\hline 7 & 70 & 68 & 4900 & 4624 & 4760 \\
\hline 8 & 65 & 59 & 4225 & 3481 & 3835 \\
\hline 9 & 61 & 56 & 3721 & 3136 & 3416 \\
\hline 10 & 72 & 63 & 5184 & 3969 & 4536 \\
\hline 11 & 57 & 53 & 3249 & 2809 & 3021 \\
\hline 12 & 65 & 53 & 4225 & 2809 & 3445 \\
\hline 13 & 74 & 61 & 5476 & 3721 & 4514 \\
\hline 14 & 58 & 45 & 3364 & 2025 & 2610 \\
\hline 15 & 66 & 49 & 4356 & 2401 & 3234 \\
\hline 16 & 61 & 55 & 3721 & 3025 & 3355 \\
\hline 17 & 59 & 59 & 3481 & 3481 & 3481 \\
\hline 18 & 69 & 53 & 4761 & 2809 & 3657 \\
\hline 19 & 62 & 54 & 3844 & 2916 & 3348 \\
\hline 20 & 62 & 50 & 3844 & 2500 & 3100 \\
\hline 21 & 66 & 50 & 4356 & 2500 & 3300 \\
\hline 22 & 58 & 53 & 3364 & 2809 & 3074 \\
\hline 23 & 60 & 52 & 3600 & 2704 & 3120 \\
\hline 24 & 61 & 59 & 3721 & 3481 & 3599 \\
\hline 25 & 59 & 54 & 3481 & 2916 & 3186 \\
\hline 26 & 70 & 61 & 4900 & 3721 & 4270 \\
\hline
\end{tabular}




\begin{tabular}{cccccc}
\hline 27 & 65 & 56 & 4225 & 3136 & 3640 \\
\hline 28 & 61 & 60 & 3721 & 3600 & 3660 \\
\hline 29 & 59 & 51 & 3481 & 2601 & 3009 \\
\hline 30 & 64 & 65 & 4096 & 4225 & 4160 \\
\hline & $\mathbf{1 8 9 4}$ & $\mathbf{1 6 7 9}$ & $\mathbf{1 2 0 5 1 2}$ & $\mathbf{9 4 8 8 1}$ & $\mathbf{1 0 6 5 2 3}$ \\
\hline
\end{tabular}

Hipotesis yang akan diuji korelasi product moment ini merupakan:

Ho $=$ Tidak Terdapat Pengaruh Pendidikan Agama Islam Di SMA Negeri 6 Kabupaten Tangerang Terhadap Pembelajaran Antikorupsi.

Hi $=$ Terdapat Pengaruh Pendidikan Agama Islam Di SMA Negeri 6 Kabupaten Tangerang Terhadap Pembelajaran Antikorupsi.

Dari data tersebut diperoleh data sebagai berikut:
$\mathrm{N} \quad=30$
$\sum \mathrm{X}^{2}=120512$
$\sum \mathrm{Y}^{2}=94881$
$\sum \mathrm{X}=1894$
$\sum \mathrm{Y}=1679$
$\sum X Y=106523$

Kemudian dimasukan ke dalam sebuah rumus korelasi product moment :

$$
\begin{aligned}
\mathrm{r}_{\mathrm{xy}} & =\frac{N \sum X Y-\left(\sum X\right)\left(\sum Y\right)}{\sqrt{\left[N \sum X^{2}-\left(\sum X\right)^{2}\right]\left[\Sigma^{2}-\left(\sum Y^{2}\right)\right]}} \\
& =\frac{30.106523-(1894)(1674)}{\sqrt{\left[30.120512-(1894)^{2}\right]\left[30.94881-(1679)^{2}\right]}} \\
& =\frac{319560-3180026}{\sqrt{(3615360-3587236)(284630-2819041)}} \\
& =\frac{15664}{\sqrt{28124.27389}} \\
& =\frac{15664}{\sqrt{770288236}} \\
& =\frac{15664}{27754} \\
& =0,564
\end{aligned}
$$

Dari perhitungan di atas, diperoleh hasil korelasi antara variabel $\mathrm{X}$ dan varaiabel Y sebesar 0,564. Jika dikonsultasikan dengan tabel angka kritik product moment taraf signifikan $5 \%$ dan $\mathrm{N}-\mathrm{nr}=28$, diperoleh nilai tabel sebesar 0,374 
dengan demikian $r_{\text {hitung }}$ lebih besar dari $r_{\text {tabel }}(0,564>0,374)$, ini berarti Ho ditolak dan Ha diterima.

Tabel 2. Nukilan Tabel Nilai Koefisien "r” Product Moment (Anas sudijono)

Df ( degres of freedom) atau

Harga "r" pada taraf signifikan

$\mathrm{db}$ (derajat bebas) dengan

rumus : $(30-2=28)$

$5 \% \quad 10 \%$

27

0,381

0,487

28

0,374

0,487

29

0,367

0,47

Dalam memberikan interprestasi secara sederhana terhadap sutau angka indeks korelasi " $\mathrm{r}$ " product moment $\left(\mathrm{r}_{\mathrm{xy}}\right)$, pada umumnya digunakan pedoman atau ancar-ancar sebagai berikut: (https://openstatistik.wordpress.com/korelasi-product-moment-pearson/)

Tabel 3. Indeks korelasi " $\mathrm{r}$ " product moment $\left(\mathrm{r}_{\mathrm{xy}}\right)$

\begin{tabular}{ll}
\hline Besarnya " $r$ " product moment $\left(\mathrm{r}_{\mathrm{xy}}\right)$ & \multicolumn{1}{c}{ Interprestasi } \\
\hline & Antara variabel X dan variabel Y \\
$0,00-0,20$ & memang terdapat korelasi, akan tetapi \\
& korelasi itu sangat lemah atau rendah \\
& sehingga korelasi itu diabaikan
\end{tabular}




\begin{tabular}{ll}
\hline $0,20-0,40$ & $\begin{array}{l}\text { Antara variabel X dan variabel Y } \\
\text { terdapat korelasi yang lemah atau } \\
\text { rendah }\end{array}$ \\
\hline $\mathbf{0 , 4 0 - 0 , 7 0}$ & $\begin{array}{l}\text { Antara variabel X dan variabel Y } \\
\text { terdapat korelasi yang sedang atau } \\
\text { cukup }\end{array}$ \\
\hline $0,70-0,90$ & $\begin{array}{l}\text { Antara variabel X dan variabel Y } \\
\text { terdapat korelasi yang kuat atau tinggi }\end{array}$ \\
\hline $0,90-1,00$ & Antara variabel X dan variabel Y \\
& terdapat korelasi yang sangat atau \\
sangat tinggi
\end{tabular}

Dari hasil perhitungan di atas, diperoleh $r_{x y}$ sebesar 0,564. Hasil ini berada pada posisi $0,40-0,70$ yang berarti antara variabel $\mathrm{X}$ dan variabel $\mathrm{Y}$ terdapat pegaruh yang sedang atau cukup.

Hal ini sama dengan penghitungan dalam uji regresi menggunakan SPSS versi 2.1 dalam analisis Uji Corelations, dimana data yang diolah diambil dari keseluruhan nilai pada variabel X dan variabel Y. Hal ini pada dasarnya sama untuk menunjukan korelasi yang signifikan antara satu variabel dengan variabel lainnya. Hal ini bisa dilihat sebagai berikut:

Tabel 4. Korelasi Variabel dengan Variabel Lainnya

\begin{tabular}{llrr}
\hline \multicolumn{3}{c}{ Correlations } & \\
\hline \\
\hline
\end{tabular}

Sumber : data yang diolah menggunakan SPSS versi 21.0

JIEBAR : Journal of Islamic Education: Basic and Applied Research 
Pada tabel di atas menunjukan hasil akhir yang sama yaitu ,564 atau 0,564 baik itu dalam penghitungan secara manual Korelasi product moment maupun menggunkan Uji Regresi dengan SPSS.

Selanjutnya untuk mengetahui dan memastikan model yang kita buat tidak bias atau untuk menghasilkan estimator perlu melakukan uji asumsi klasik yang dikenal dengan istilah BLUE (Best Linear Unbiased Estimator) dengan menggunakan SPSS. Maka dari itu penulis sudah melakukan 2 pengujian, yang pertama uji Normalitas yaitu untuk melihat apakah data penelitian terdistribusi normal atau tidak, yang kedua uji Heteroskedastisitas yaitu untuk melihat ada atau tidaknya penyimpangan heteroskedastisitas pada model regresi.

Dari 2 Uji Asumsi Klasik (Uji Normalitas dan Uji Heteroskedastisitas) untuk mengetahui hasil dari pengujian itu sendiri dapat dilihat dibawah ini:

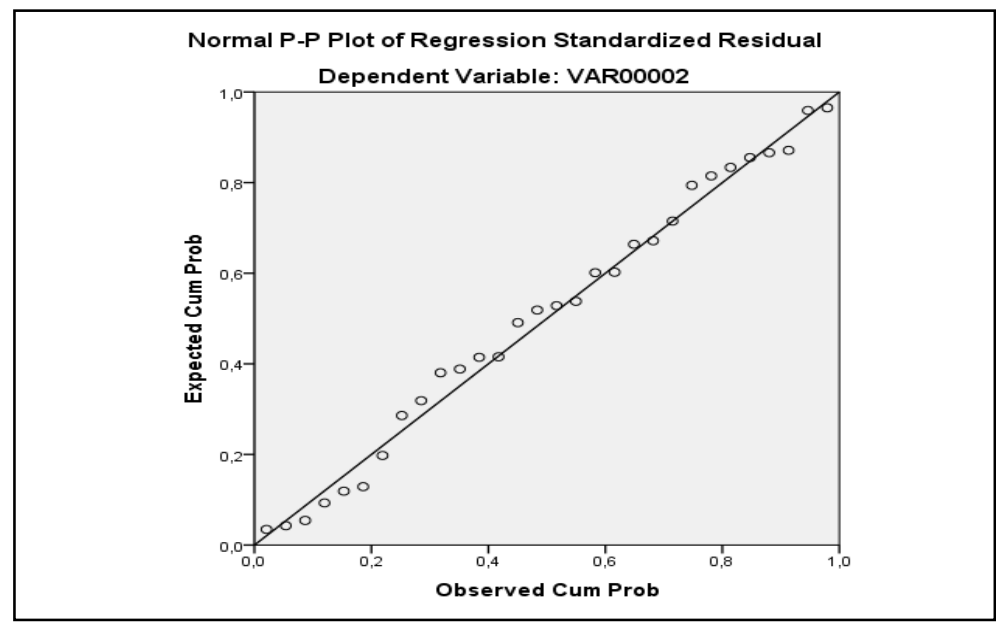

Gambar 1. Uji Normalitas dan Uji Heteroskedastisitas

Sumber : Data yang diolah menggunakan SPSS versi 21.0

Dari Gambar di atas Uji Normalitas dapat dikatakan model lulus karena letak titik-titik berada di sepanjang garis (Tidak terputus, tidak berada jauh dari garis). 


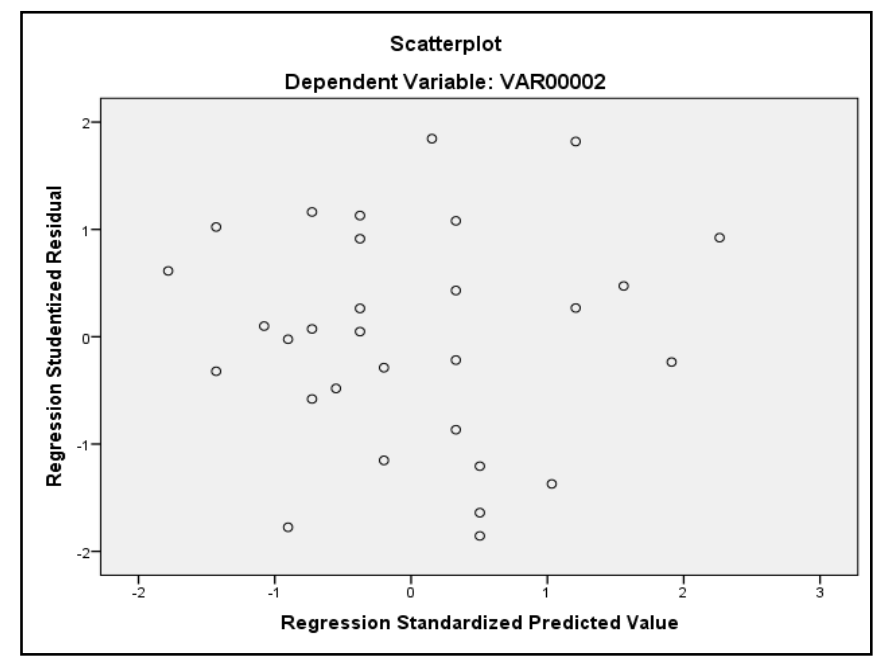

Gambar 2. Uji Heteroskedastisitas

Sumber : data yang diolah menggunakan SPSS versi 21.0

Dari gambar di atas Uji Heteroskedastisitas dapat dikatakan model lulus karena titik-titik pada grafik tidak membentuk suatu pola tertentu yang teratur, dan titik-titik pada grafik menyebar di atas dan di bawah angka 0 pada sumbu Y.

Sebagai langkah terakhir untuk mengetahui besarnya pengaruh antara variabel $\mathrm{X}$ dan variabel $\mathrm{Y}$, maka dicari angka signifikan determinasi $\mathrm{r}^{2}$, yaitu dengan menggunkan rumus sebagai berikut:

$$
\begin{aligned}
\mathrm{KD} & =\mathrm{r}^{2} \cdot 100 \% \\
& =(0,56)^{2} \cdot 100 \% \\
& =\mathbf{3 1} \mathbf{3} \mathbf{3 6} \%
\end{aligned}
$$

\section{KESIMPULAN}

Berdasarkan hasil penelitian penulis maka dapat disimpulkan bahwa terdapat pengaruh yang signifikan antara pendidikan Agama Islam terhadap pembelajaran antikorupsi di SMA Negeri 6 Kabupaten Tangerang, hal ini dapat dilihat dari hasil korelasi antara variabel $\mathrm{X}$ dan variabel $\mathrm{Y}$ yaitu sebesar 0,564 atau,564. Dengan demikian $r_{\text {ritung }}$ lebih besar dari $\mathrm{r}_{\text {tabel }}(0,564>0,374)$, dalam hal ini maka Ho ditolak dan $\mathrm{Ha}$ diterima. Dan angka koefisien determinasi 
menunjukan 31,36\%. Maka dalam hal ini pendidikan Agama Islam memiliki ruang gerak yang cukup dalam mewujudkan siswaataui yang menjadikan Islam sebagai pandangan hidupnya.

\section{REFERENSI}

Abu Fida’ Ab dur Rafi', 2006. Terapi Penyakit Korupsi Jakarta: Republika

Anas Salahudin dan Irwanto Alkriencehie, 2013. Pendidikan Karakter Pendidikan Berbasis Agama Dan Budaya Bangsa, Bandung: Pustaka Setia

Ari Wibowo, 2012. Pendidikan Antikorupsi Di Sekolah, Yogyakarta: Pustaka Pelajar

Departemen Agama RI, 2005. Mushaf Al-Qur'an Terjemah, (Jakarta: Kelompok Gema Insani

Departemen Pendidikan Nasional, 2002. Kamus Besar Bahasa Indonesia. Jakarta: Balai Pustaka

Endin Nasrudin, 2008. Psikologi Pembelajaran, Sukabumi: STAI Sukabumi Publishing

Evi, Hartanti, 2008. Tindak Pidana Korupsi Edisi Kedua, Jakarta: Sinar Grafika

HR. Ibnu Majah dalam kitab al Jihad, bab al Ghulul, hadits no.2850, dishahihkan oleh Syaikh al Albani dalam Shahih Sunan Ibnu Majah dan Shahihul Jami'ish Shaghir, no. 7869

Jusuf Kalla, 2009. Korupsi Mengorupsi Indonesia, Jakarta : PT. Gramedia Pustaka Utama

Muzayin Arifin, 2000. Filsafat Pendidikan Islam, Jakarta : Bumi Aksara

Prodjohamidjojo, 2011. Martiman, Penerapan Pembuktian Terbalik Dalam Delik Korupsi “UU No. 31 Tahun 1999”, Bandung: CV. Mandar Maju

Republika Indonesia, 2003. Undang-Undang Republik Indonesia Nomor 20 Tabun 2003 Tentang Sistem Pendidikan Nasional, Jakarta: Republika Indonesia

Singgih Santoso, 2000. SPSS 22 From Essential To Expert Skills, Jakarta : PT. Elex Media Komputindo 
Soelaiman Joesoef, 1992. Konsep Dasar Pendidikan Luar Sekolah, Cet. I, Jakarta: Bumi Aksara

Sri Minarti, 2013. Ilmu Pendidikan Islam, Jakarta: AMZAH

Sugiyono, 2017. Metode Penelitian: Kuantitatif, Kualitatif, dan R \& D, Bandung: Alfabeta

Suharsimi Arikunto, 1992. Prosedur Penelitian, Jakarta: Rineka Cipta

Sulaiman Rasjid, 2012. Fiqib Islam, Bandung: Sinar Baru Algesindo

Surachmin dan Cahaya Suhandi, 2011. Strategi dan Teknik Korupsi "Mengetahui Untuk Mencegah”, Jakarta: Sinar Grafika

Zamroni, 2000. Paradigma Pendidikan Masa Depan, Yogyakarta: Bigraf Publishing

Model dan Perangkeat Pembelajaran Pendidikan Antikorupsi Pada Pendidikan Agama Islam di Sekolah Menengah Atas (SMA), h.201-202, dari http://digilib.uinsby.ac.id80647BAB\%20V.pdf

https://openstatistik.wordpress.com/korelasi-product-moment-pearson/ 